\title{
Pengembangan Media Pembelajaran Matematika Berbasis Audio Visual Yang Interaktif Pada Masa Pembelajaran Jarak Jauh
}

(Developing Mathematics Learning Media by Interaktif Audio Visual in Pembelajaran Jarak Jauh)

\author{
Muhammad Syarwa Sangila ${ }^{1}$, Asran $^{2} \&$ Isra Ardianto ${ }^{3}$ \\ ${ }^{1}$ Tadris Matematika, FTIK, IAIN Kendari;email: syarwa1990@ gmail.com \\ ${ }^{2}$ Pendidikan Matematika FKIP UHO; email: asran_math@yahoo.co.id \\ ${ }^{3}$ Tadris Matematika, FTIK, IAIN Kendari email: israardianto@yahoo.co.id
}

\begin{abstract}
Abstrak: Penelitian ini bertujuan untuk mengetahui kelayakan media pembelajaran matematika berbasis audio visual yang dihasilkan. Metode penelitian yang digunakan adalah research and development dengan menggunakan model Hannafin \& Peck. Tahap penelitian terdiri dari tiga tahap yaitu tahap analisis kebutuhan, desain, dan pengembangan/implementasi. Instrumen yang digunakan berupa angket dan wawancara. Angket penilaian diberikan kepada empat orang ahli media dan ahli materi. Hasil penelitian menunjukan bahwa media pembelajaran matematika berbasis audio visual dapat dikategorikan sangat layak untuk digunakan dalam pembelajaran menurut penilaian dari ahli media dan ahli materi, masing-masing memberi skor penilaian $84,32 \%$ dari ahli media dan $68,33 \%$ dari ahli materi.
\end{abstract}

Kata kunci: Media Pembelajaran Berbasis Audio Visual

\begin{abstract}
This study aims to determine the feasibility of the resulting audio-visual based mathematics learning media. The research method used is research and development using the Hannafin \& Peck model. The research stage consists of three stages, namely the needs analysis, design, and development / implementation stages. The instruments used were questionnaires and interviews. The assessment questionnaire was given to four media experts and material experts. The results showed that audio-visual based mathematics learning media could be categorized as very feasible to use in learning according to the assessment of media experts and material experts, each of which gave an assessment score of $84.32 \%$ from media experts and $68.33 \%$ from material experts.
\end{abstract}

Keywords: Audio Visual Learning Media

\section{PENDAHULUAN}

Pendidikan pada dasarnya merupakan interaksi antara pendidik dengan peserta didik, untuk mencapai tujuan pendidikan, yang berlangsung dalam lingkungan tertentu. (Yani, 2017). Interaksi antara pendidik dengan peserta didik yang dimaksud dalam hal ini yaitu proses pembelajaran yang dilakukan secara formal di lembaga pendidikan atau sekolah. Namun pada saat ini dengan adanya virus COVID-19 di Indonesia saat ini berdampak bagi seluruh masyarakat. Pandemi COVID-19 adalah krisis kesehatan yang pertama dan terutama di dunia. Banyak negara memutuskan untuk menutup sekolah, perguruan tinggi dan universitas (Purwanto dkk, 2020).

Pada tanggal 24 maret 2020 Menteri Pendidikan dan Kebudayaan Republik Indonesia mengeluarkan Surat Edaran Nomor 4 Tahun 2020 Tentang Pelaksanaan Kebijakan Pendidikan Dalam Masa Darurat Penyebaran COVID, dalam Surat Edaran 
tersebut dijelaskan bahwa proses belajar dilaksanakan di rumah melalui pembelajaran daring/jarak jauh dilaksanakan untuk memberikan pengalaman belajar yang bermakna bagi siswa. Belajar di rumah dapat difokuskan pada pendidikan kecakapan hidup antara lain mengenai pandemi Covid-19.

Dampak yang dirasakan murid pada proses pembelajaran di rumah yaitu murid belum ada budaya belajar jarak jauh karena selama ini sistem belajar dilaksanakan adalah melalui tatap muka, murid terbiasa berada di sekolah untuk berinteraksi dengan teman-temannya, bermain dan bercanda gurau dengan temantemannya serta bertatap muka dengan para gurunya, dengan adanya metode pembelajaran jarah jauh membuat para murid perlu waktu untuk beradaptasi dan mereka menghadapi perubahan baru yang secara tidak langsung akan mempengaruhi daya serap belajar mereka. Sedangkan dampak yang dirasakan guru yaitu tidak semua mahir menggunakan teknologi internet atau media sosial sebagai sarana pembelajaran, beberapa guru senior belum sepenuhnya mampu menggunakan perangkat atau fasilitas untuk penunjang kegiatan pembelajaran online dan perlu pendampingan dan pelatihan terlebih dahulu (Purwanto dkk, 2020).

Kondisi demikian juga dialami oleh siswa di SMP Negeri 1 Konawe Selatan, berdasarkan hasil wawancara dengan salah satu guru matematika menyampaikan bahwa kendala yang dihadapi adalah tidak semua siswa mampu mengikuti proses pembelajaran disebabkan ada sebagian siswa yang tidak mempunyai smartphone dan ada yang tidak mempunyai kuota internet untuk mengikuti pembelajaran daring. Selain itu, guru belum bisa membuat inovasi media pembelajaran menggunakan teknologi komputer.

Dengan mengetahui masalah seperti tersebut di atas maka sebagai pendidik matematika perlu memahami dan mengembangkan berbagai metode dalam proses pembelajaran matematika. Hal ini disebabkan karena dalam mempelajari matematika siswa harus berpikir agar mampu memahami konsep-konsep matematika yang dipelajari serta mampu menggunakan konsep-konsep tersebut secara tepat ketika ia harus mencari jawaban dari berbagai soal matematika (Sabandar, 2013). Hal inilah yang menjadi polemik yang sulit didapat dari pembelajaran jarak jauh.

Ada banyak modus pembelajaran jarak jauh yang dapat dijadikan alternatif pembelajaran antara lain dengan menggunakan aplikasi e-learning, media konferensi, media sosial, dan lain-lain. Penggunaan aplikasi seperti ini dipandang membantu dalam proses belajar mengajar. Di sisi lain, penggunaan media online tersebut dalam waktu jangka panjang dipandang boros dalam penggunaan kuota sehingga dikeluhkan oleh banyak pengguna. Oleh karena itu pengembangan media yang efektif sekaligus ekonomis menjadi tantangan tersediri. Pengembangan media pembelajaran yang sederhana dan ekonomis tanpa menghilangkan esensi sisi 
efektivitasnya dapat dilakukan dengan mengoptimalkan media pembelajaran berbasis audio visual. Media pembelajaran berbasis audio visual diprogram dan dirancang untuk dipakai oleh siswa secara individual (belajar mandiri). Saat siswa mengaplikasikan program ini, siswa diajak untuk terlibat secara auditif, visual dan kinetik, sehingga dengan pelibatan ini dimungkinkan informasi atau pesan mudah untuk dimengerti (Salamah, 2017).

Media pembelajaran berbasis audio visual selain bisa digunakan untuk membantu siswa dalam memahami materi juga bisa digunakan sebagai media pengganti ketika seorang guru tidak dapat memberi pelajaran dikarenakan suatu hal. Media ini bisa mewakili guru dalam memberikan materi sehingga siswa tetap mendapatkan masukan pengetahuan melalui media tersebut dan terget atau tujuan mengajarpun tercapai. Dengan menghadirkan media audio visual maka semua anak didik dapat menikmati media tersebut sekaligus menyerap ilmu melalui media itu. Selanjutnya, media audio visual dapat menghadirkan benda-benda, beberapa obyek dan gerakan-gerakan tertentu yang sekiranya sulit menghadirkan hal-hal tersebut langsung di dalam kelas (Lestari, 2013).

Dengan media pembelajaran audio visual ini menjadikan guru bukan satusatunya sumber belajar bagi siswa melainkan media audio visual juga diharapkan bisa membuat siswa tertarik dan aktif dalam proses pembelajaran. Sehingga media pembelajaran berbasis audio visual dapat dimanfaatkan sebagai perantara dalam pembelajaran jarak jauh khususnya pada masa pendemi seperti sekarang ini. Selain itu, penggunaan media audio visual mampu mengkongkritkan objek yang siswa pelajari, siswa dapat melihat, mendengar, dan merasakan secara langsung atau nyata apa yang mereka pelajari, sehingga dapat merangsang partisipasi aktif siswa dalam belajar dan secara tidak langsung memberikan pemahaman yang mendalam tentang apa yang dipelajari, sehingga hasil belajar meningkat (Agustini dkk, 2016).

\section{METODE PENELITIAN}

Jenis penelitian yang digunakan adalah jenis penelitian $\mathrm{R} \& \mathrm{D}$ (Research and Development). Research and Development adalah metode penelitian yang digunakan untuk menghasilkan produk tertentu dan menguji keefektifan metode tersebut. Dalam bidang pendidikan, penelitian dan pengembangan atau Research and Development, merupakan metode penelitian yang digunakan untuk mengembangkan atau memvalidasi produk-produk yang digunakan dalam pendidikan dan pembelajaran (Hanafi, 2017). Dalam penelitian ini model pengembangan yang dilakukan dengan mengadaptasi model Hannafin dan Peck, karena model Hannafin dan Peck adalah model yang sederhana, namun elegan (Tegeh, 2014). Model Hannafin dan Peck terdiri dari tiga fase, yaitu fase analisis kebutuhan (need assess), fase desain 
(design), dan fase pengembangan (develop) atau implementasi. Secara lebih jelas, model Hannafin dan Peck ini dapat dilihat pada Gambar 1.

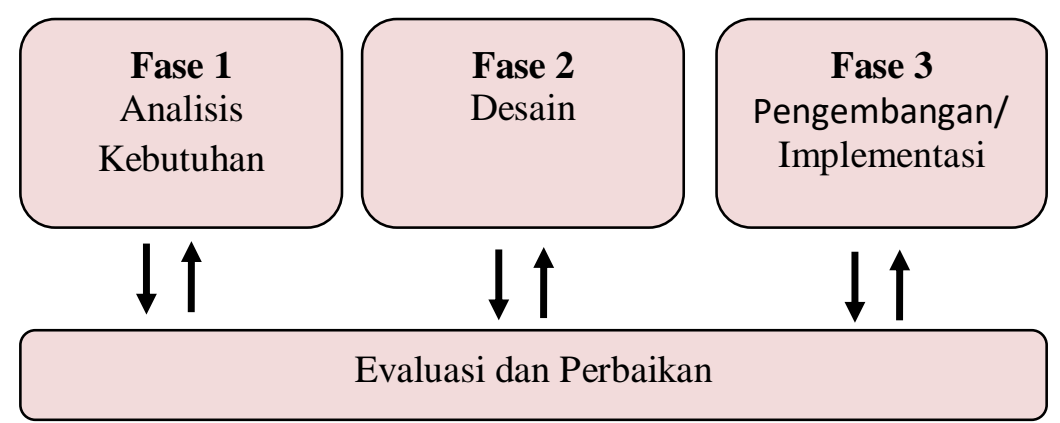

\section{Gambar 1. Adaptasi model Hannafin dan Peck}

Prosedur dalam penelitian ini terdiri dari beberapa tahapan. Pertama, analisis kebutuhan yang bertujuan untuk mengidentifikasi berbagai kebutuhan dalam mengembangkan suatu produk media pembelajaran, termasuk didalamnya tujuan media pembelajaran yang dibuat, pengetahuan, kemahiran sasaran, dan peralatan yang diperlukan. Kedua adalah desain, pada tahap ini bertujuan untuk mengidentifikasi dan mendokumentasikan kaidah yang terbaik untuk mencapai tujuan pembuatan media pembelajaran tersebut. Salah satu bentuk yang dihasilkan dari fase ini adalah dokumen storyboard yang mengikuti urutan aktivitas berdasarkan keperluan peserta didik dan media pembelajaran. Tahapan ketiga adalah pengembangan dan implementasi. Aktivitas yang dihasilkan dari tahap ini adalah berupa diagram alur, pengujian, serta penilaian sumatif dan penialain formatif. Dokumen storyboard dijadikan sebagai landasan untuk pembuatan diagram alur yang dapat membantu proses pembuatan media pembelajaran (Ernawati, 2017).

Teknik pengumpulan data yang dilakukan pada penelitian ini adalah teknik angket. Angket ini diberikan kepada ahli media, ahli materi, yang terdiri dari dosen matematika dan guru matematika. Data penilaian yang diperoleh dari validator dianalisis secara deskriptif kualitatif dan dijadikan sebagai acuan untuk merevisi produk, sehingga menghasilkan produk yang layak. Desain produk yang dikembangkan dinilai oleh validator dengan menggunakan lembar validasi.

Tabel 1.

Kriteria Kelayakan Media

\begin{tabular}{ccc}
\hline No & Skor Dalam Persen (\%) & Kategori Kelayakan \\
\hline 1 & $<21 \%$ & Sangat Tidak Layak \\
2 & $21-40 \%$ & Tidak Layak \\
3 & $41-60 \%$ & Cukup Layak \\
4 & $61-80 \%$ & Layak \\
5 & $81-100 \%$ & Sangat Layak \\
\hline
\end{tabular}

Layak atau tidak layaknya produk media pembelajaran interaktif dapat diketahui dengan melihat hasil dari validasi ahli. 


\section{HASIL PENELITIAN}

\section{Hasil Uji Validasi oleh Ahli Media}

Validasi ahli media dilakukan oleh dua orang validator yang merupakan dosen pendidikan matematika dan dosen media pembelajaran IAIN Kendari. Hasil uji validasi oleh ahli media berupa hasil tanggapan dan penilaian dari ahli media, kemudian dari hasil data yang diperoleh dianalisis dan dilakukan revisi produk sesuai dari saran. Berikut hasil penilaiannya disajikan pada Tabel 2 berikut.

Tabel 2.

Rata-rata Persentase Hasil Uji Validasi Ahli Media

\begin{tabular}{cccc}
\hline Aspek Penilaian & Ahli 1 (\%) & Ahli 2 (\%) & Rata-rata (\%) \\
\hline Auxiliary information & 85,00 & 90,00 & 87,50 \\
Interface & 83,33 & 86,66 & 84,99 \\
Navigation & 85,00 & 60,00 & 72,50 \\
Pedagogy & 100,00 & 100,00 & 100 \\
Robustness & 76,66 & 76,66 & 76,66 \\
\hline & Total & 84,32 \\
\hline
\end{tabular}

Tabel 2 menunjukkan bahwa rata-rata skor ditinjau dari aspek Auxiliary Information dari dua ahli yaitu memperoleh nilai rata-rata $87,50 \%$. Berdasarkan aspek Interface memperoleh data rata-rata 84,99\%. Aspek Navigation memperoleh data rata-rata $72,50 \%$. Aspek Pedagogy memperoleh data rata-rata 100,00\%. Aspek Robustness memperoleh data rata-rata 76,66\%. Adapun total presentase dari keseluruhan aspek yang diperoleh dari dua ahli adalah 84,32\%, sehingga dapat disimpulkan bahwa media pembelajaran berbasis audio visual dikategorikan sangat layak untuk digunakan.

\section{Hasil Uji Validasi oleh Ahli Materi}

Validasi ahli materi dilakukan oleh dua orang validator yang merupakan guru matematika SMP Negeri 1 Konawe Selatan. Hasil uji validasi oleh ahli materi berupa hasil tanggapan dan penilaian dari ahli materi, kemudian dari hasil data yang diperoleh dianalisis dan dilakukan revisi produk sesuai dari saran. Berikut hasil penilaiannya disajikan pada Tabel 3 berikut.

Tabel 3.

Rata-rata Persentase Hasil Uji Validasi Ahli Materi

\begin{tabular}{cccc}
\hline Aspek Penilaian & Ahli 1 (\%) & Ahli 2 (\%) & Rata-rata (\%) \\
\hline Subject Matter & 80,00 & 80,00 & 80,00 \\
Auxiliary Information & 65,00 & 65,00 & 65,00 \\
Pedagogy & 60,00 & 60,00 & 60,00 \\
\hline \multicolumn{3}{c}{ Total } & 68,33 \\
\hline
\end{tabular}

Pengembangan Media Pembelajaran Matematika Berbasis Audio Visual Yang Interaktif Pada Masa Pembelajaran Jarak Jauh (Muhammad Syarwa Sangila, Asran dan Isra Ardianto) 
Tabel 3 menunjukkan bahwa rata-rata skor ditinjau dari aspek Subject Matter dari dua ahli yaitu memperoleh nilai rata-rata 80,00\%. Berdasarkan aspek Auxiliary Information memperoleh data rata-rata 65,00\%. Aspek Pedagogy memperoleh data rata-rata $60,00 \%$. Adapun total persentase dari keseluruhan aspek yang diperoleh dari dua ahli adalah 68,33\%, sehingga dapat disimpulkan bahwa media pembelajaran berbasis audio visual dikategorikan layak untuk digunakan

\section{PEMBAHASAN}

Pengembangan media pembelajaran berbasis audio visual ini diawali dengan tahap analisis kebutuhan. Pada tahap ini langkah awal yang peneliti lakukan adalah mengidentifikasi kebutuhan-kebutuhan dalam mengembangkan suatu media pembelajaran termasuklah di dalamnya tujuan dan objektif media pembelajaran yang dibuat, pengetahuan dan kemahiran yang diperlukan oleh kelompok sasaran, peralatan dan keperluan media pembelajaran. Tahap kedua yaitu tahap desain, pada tahap ini peneliti membuat storyboard dari media pembelajaran. Dan tahap ketiga adalah pengembangan dan implementasi.

Pada tahap analisis kebutuhan peneliti melakukan wawancara dengan guru mata pelajaran matematika SMP Negeri 1 Konawe Selatan. Berdasarkan hasil wawancara diketahui bahwa proses pembelajaran sudah didukung oleh fasilitas media pembelajaran seperti komputer dan LCD Proyektor bahkan siswa diperbolehkan membawa smartphone jika dalam proses pembelajaran memang membutuhkan smartphone sebagai media yang dapat memperlancar proses pembelajaran. Namun, meskipun demikian guru jarang menggunakan media dalam proses pembelajarannya dikarenakan mereka masih belum bisa membuat inovasi media pembelajaran menggunakan teknologi komputer. Kurangnya media pembelajaran yang inovatif dalam pembelajaran menjadi kendala tersendiri dalam pembelajaran, sehingga akan lebih efektif jika guru dapat menemukan inovasi dalam membuat media pembelajaran. Pada tahap ini peneliti juga menganalisis mengenai materi pelajaran yang sulit dipahami oleh siswa. Dari hasil wawancara diperoleh bahwa pokok bahasan tentang pola bilangan sangat susah untuk dipahami. Hal ini disebabkan karena banyak siswa yang telah lupa mengenai materi bilangan pada materi pelajaran di kelas sebelumnya. Selain dipengaruhi metode pembelajaran, hal ini diduga terjadi karena siswa langsung berhubungan dengan konsep yang abstrak bahkan ada yang mengandalkan hafalan tanpa memahami esensi materi yang dipelajari. Padahal sesuai kurikulum 2013, pola bilangan menempati posisi strategis dalam pembelajaran karena konsep pola bilangan sangat aplikatif dalam kehidupan sehari-hari mulai dari pola yang sengaja dibuat oleh manusia seperti pola pemberian nomor rumah sampai pada pola yang ada di alam seperti pola bilangan Fibonacci 
pada aneka bungadan hewan (Disnawati \& Nahak, 2019). Sehingga dengan menggunakan media pembelajaran berbasis audio visual dapat mempermudah guru untuk menyampaikan materi pola bilangan.

Tahap selanjutnya setelah dilakukan analisis kebutuhan adalah tahap desain. Pada tahap desain peneliti merancang storyboard mulai dari tampilan yang terdiri dari halaman menu utama, halaman kompetensi dasar, halaman tujuan pembelajaran/pengalaman belajar, halaman materi pelajaran, halaman evaluasi, halaman petunjuk dan terakhir halaman profil. Pada tahap ini peneliti juga melakukan pemilihan software yang akan digunakan dalam pengembangan produk yang terdiri atas tiga software yaitu pertama aplikasi Microsoft Office Power Point yang merupakan aplikasi utama dalam pembuatan media pembelajaran, pada aplikasi Microsoft Office Power Point peneliti membuat background setiap halaman dan menu pada storyboard yang telah dirancang. Kedua aplikasi TTSReader merupakan aplikasi berbasis android yang berfungsi untuk mengubah teks menjadi suara, pada aplikasi TTSReader peneliti membuat teks yang akan dijadikan suara untuk dimasukkan ke dalam media pembelajaran agar materi yang ditampilkan bisa lebih interaktif dengan siswa. Dan aplikasi ketiga yaitu Audacity yang berfungsi untuk mengedit suara yang telah di buat pada aplikasi TTSReader. Karena suara yang dihasilkan pada aplikasi TTSReader berformat MP3, sedangkan pada aplikasi Microsoft Power Point hanya mendukung formart WAV untuk suara sehingga perlu diedit pada aplikasi Audacity.

Tahap ketiga adalah pengembangan dan implementasi. Pada tahap ini peneliti membuat diagram alur atau flowchart serta penilaian formatif yang dilakukan sepanjang proses pengembangan meedia pembelajaran. Pembuatan flowchart didasarkan pada storyboard yang telah dibuat pada tahap desain. Pengembangan media pembelajaran berbasis audio visual dimulai dengan membuat background dari masing-masing halaman yang telah dibuat pada storyboard, membuat dan menambahkan icon untuk tombol menu, suara, next, back, home dan keluar. Kemudian tombol-tombol tersebut dihubungkan dengan hyperlink agar berjalan sesuai intruksi yang diberikan. Pada halaman materi peneliti membuat narasi teks yang kemudian ditambahkan audio serta animasi. Untuk halaman evaluasi, kuis dibuat dengan bahasa program (Visual Basic) setelah kuis telah dibuat maka media disimpan dalam bentuk Powerpoint Enabled Macros. Penyimpanan dalam bentuk ini sangat penting karena jika tidak maka kuis yang dibuat tidak akan bisa dijalankan.

Validasi oleh para ahli adalah tahap yang dilakukan setelah pengembangan media selesai. Tahap ini bertujuan untuk mengetahui kelayakan media membelajaran berbasis Audio Visual. Validator terdiri dari empat orang ahli, yaitu dua orang ahli media dan dua orang ahli materi. Dua valiadator ahli media merupakan dosen IAIN 
Kendari. Sedangkan ahli materi terdiri dari dua orang guru matematika SMP Negeri 1 Konawe Selatan. Untuk penilaian media, dapat ditinjau dari lima aspek, yaitu pertama aspek Auxiliary information yang terdiri atas dua indikator yaitu Petunjuk dan Bantuan. Kedua aspek Interface terdiri atas lima indikator yaitu Kualitas teks, Animasi, Audio, Video, dan Gambar. Ketiga aspek Navigation terdiri atas dua indikator yaitu Bantuan navigasi dan Konsistensi. Keempat aspek Pedagogy yang indikatornya adalah Kontrol pengguna. Dan kelima adalah aspek Robustness yang terdiri dari tiga indikator yaitu Untuk pengguna umum, Untuk pengguna yang tidak umum, dan Pada komputer yang berbeda. Untuk penilaian materi, dapat ditinjau dari tiga aspek, yaitu pertama aspek Subject matteryang terdiri atas empat indikator yaitu Kesesuaian tujuan, Struktur isi, Keakuratan isi, dan Bahasa. Kedua aspek Auxiliary information terdiri atas dua indikator yaitu Pengenalan, dan Kesimpulan. Dan ketiga adalah aspek Pedagogy yang terdiri dari enam indikator yaitu Metodologi, Kapasitas kognitif, Strategi pembelajaran, Pertanyaan Jawaban pertanyaan dan Kualitas umpan balik.

Setelah dilakukan pengembangan dan dilakukan validasi media pembelajaran berbasis audio visual, maka hasil penelitian media pembelajaran berbasis audio visual dikategorikan sangat layak untuk digunakan berdasarkan penilaian dari ahli media dan ahli materi. Penilaian yang dinilai dari lima aspek untuk media meliputi aspek auxiliary information, aspek interface, aspek navigation, aspek pedagogy dan aspek robustness. Dan materi dinilai dari tiga aspek yang meliputi aspek subject matter, auxiliary information, dan pedagogy. Jadi, dapat disimpulkan bahwa media pembelajaran berbasis audio visual tersebut siap dan sangat layak digunakan untuk pembelajaran.

Dengan adanya teknologi saat ini, banyak kemudahan untuk melakukan pembelajaran jarak jauh, ada berbagai media pembelajaran yang bisa digunakan oleh guru, misalnya media audio visual (Chohan, 2020). Oleh karena itu menurut penulis penerapan media pembelajaran berbasis audio visual dalam pembelajaran jarak jauh sangat efektif untuk dimanfaatkan. Hal ini sejalan dengan penelitian sebelumnya yang relevan dengan penelitian ini, yaitu penelitian oleh Andriani (2019) yang menyatakan bahwa siswa dapat menggunakan media pembelajaran audio visual film kartun matematika dirumah dan dapat juga digunakan dimana saja apabila mereka menggunakan laptop.

\section{KESIMPULAN}

Berdasarkan hasil dan pembahasan, kesimpulan dari penelitian ini adalah media pembelajaran berbasis audio visual dapat dikategorikan sangat layak untuk digunakan dalam pembelajaran menurut penilaian dari ahli media dan ahli materi, 
masing-masing memberi skor penilaian 84,32\% dari ahli media, dan 68,33\% dari ahli materi. Skor tersebut masuk dalam kategori sangat layak. Sehingga media ini siap dan sangat layak digunakan untuk pembelajaran.

\section{Daftar Pustaka}

Agustini, P. P., Kristiantari, M. R., \& Putra, D. K. N. S. (2016). Penerapan Model Pembelajaran Berbasis Masalah Berbantuan Media Audio Visual Untuk Meningkatkan Hasil Belajar Keterampilan Menyimak Tema Sejarah Peradaban Indonesia Pada Siswa Kelas V Sdn 8 Sumerta. Mimbar PGSD Undiksha, 4(1).

Andriani, T. (2019). Peningkatan Minat Belajar Matematika Siswa Melalui Media Pembelajaran Audio Visual Film Kartun Matematika Pada Materi Bangun Ruang Di Kelas Viii (Doctoral Dissertation, Universitas Labuhanbatu).

Chohan, M. S. N. Penggunaan Media Audio-Visual Berbasis Animasi Dalam Menunjang Pembelajaran Jarak Jauh.

Disnawati, H., \& Nahak, S. (2019). Pengembangan Lembar Kerja Siswa Berbasis Etnomatematika Tenun Timor Pada Materi Pola Bilangan. Jurnal Elemen, 5(1), 64-79.

Ernawati, I. (2017). Uji Kelayakan Media Pembelajaran Interaktif Pada Mata Pelajaran Administrasi Server. Elinvo (Electronics, Informatics, And Vocational Education), 2(2), 204-210.

Hanafi, H. (2017). Konsep Penelitian R\&D Dalam Bidang Pendidikan. Banten: UIN Sultan Maulana Hassanuddin Banten.

Lestari, I. (2013). Pengembangan Bahan Ajar Berbasis Kompetensi. Padang: Akademia Permata, 1.

Kebudayaan, M. P. D., \& Indonesia, R. (2020). Surat Edaran Nomor 4 Tahun 2020 Tentang Pelaksanaan Kebijakan Pendidikan Dalam Masa Darurat Penyebaran Coronavirus Disease (COVID-19).

Purwanto, A., Pramono, R., Asbari, M., Hyun, C. C., Wijayanti, L. M., \& Putri, R. S. (2020). Studi Eksploratif Dampak Pandemi COVID-19 Terhadap Proses Pembelajaran Online Di Sekolah Dasar. Edupsycouns: Journal Of Education, Psychology And Counseling, 2(1), 1-12.

Sabandar, J. (2013). Berpikir Reflektif Dalam Pembelajaran Matematika. Tersedia Di Website: Http://File. Upi. Edu/ Direktoril Fpmipal Jur._Pend. _Matematika/194705241981031-Jozua_Sabandar/

Kumpulan_Makalah_Dan_Jurnal/ Berpikir_Reflektif2. Pdf.(Diakses Tanggal 08 Oktober 2017).

Salamah, E. R. (2017). Pengembangan Media Pembelajaran Berbasis Audio Visual Tokoh-Tokoh Kemerdekaan Indonesia. Premiere Educandum, 7(01), 9-18.

Tegeh, I. M., Jampel, I. N., \& Pudjawan, K. (2014). Model Penelitian Pengembangan. Yogyakarta: Graha Ilmu.

Pengembangan Media Pembelajaran Matematika Berbasis Audio Visual Yang Interaktif Pada Masa Pembelajaran Jarak Jauh (Muhammad Syarwa Sangila, Asran dan Isra Ardianto) 
Junianto, D., \& Wagiran, W. (2013). Pengaruh Kinerja Mengajar Guru, Keterlibatan Orang Tua, Aktualisasi Diri Dan Motivasi Berprestasi Terhadap Prestasi. Jurnal Pendidikan Vokasi, 3(3).

Yani, N. (2017). Upaya Meningkatkan Hasil Belajar Siswa Dengan Model Pembelajaran Kooperatif Tipe Investigasi Kelompok Pada Mata Pelajaran Fiqih Materi Pokok Shalat Jumat Di Kelas Vii Di Mts. Al-Hasanah Medan (Doctoral Dissertation, Universitas Islam Negeri Sumatera Utara). 